Г.В. Пєвцов ${ }^{1}$, П. Пацек ${ }^{2}$, М.В. Касьяненко ${ }^{3}$, С.В. Залкін ${ }^{1}$, С.О. Сідченко ${ }^{1}$, К.І. Хударковський ${ }^{1}$

${ }^{1}$ Харківський національний університет Повітряних Сил ім. І. Кожедуба, Харків

${ }^{2}$ Академія військового мистецтва, Варшава

${ }^{3}$ Департамент військової освіти і науки Міністерства оборони Украӥни, Київ

\title{
МЕТОДИЧНИЙ ПІДХІД ДО ВИБОРУ ЗАСОБУ МАСОВОЇ КОМУНІКАЦІЇ ДЛЯ ЗДІЙСНЕННЯ ІНФОРМАЦІЙНОГО (ПСИХОЛОГІЧНОГО) ВПЛИВУ
}

У статті визначені загальні тренди розвитку інформаційного простору як середовища для проведення інформаційних та психологічних операцій (впливів), представлений методичний підхід до вибору засобу масової комунікації в ході підготовки і проведення інформаційної (психологічної) операції (впливу), в основу якого покладений критерій “результат / вартість”. Для вибору засобу масової комунікації запропонована низка характеристик, які можуть бути оцінені відповідними показниками шляхом проведення опитування за допомогою спеціально розроблених анкет. Визначення узагальненого показника ефективності застосування засобу масової комунікації дозволяє обирати засіб масової комунікації, який найбільще відповідає ичілям інформаційного (психологічного) впливу. Економічна складова узагальненого показника ефективності застосування засобу масової комунікацї визначається, виходячи із загальної суми витрат на розробку і розміщення інформаційного контенту.

Ключові слова: інформаційний (психологічний) вплив, інформаційна (психологічна) операція, об'єкт інформаційного впливу, ичільова аудиторія.

\section{Вступ}

Постановка проблеми. Характерними рисами сучасної збройної боротьби у світі є суттєве зростання ролі протиборства в інформаційній сфері, інтенсивний розвиток інформаційної інфраструктури збройних сил провідних країн світу, розширення спектру інформаційних загроз, під якими розуміються фактори або їх сукупність, що створюють небезпеку функціонуванню суспільства та збройних сил в інформаційному просторі. На сьогоднішній день інформаційні (IO) та психологічні операції (ПсО) та інформаційні впливи (IB) стали невід’ємною складовою збройної боротьби [1-7].

Розробка й апробація провідними країнами світу концептуальних і технологічних основ мережецентричних війн, технологій штучного інтелекту, робототехнічних систем та загострення інформаційної боротьби у світовій комп'ютерній мережі Інтернет, яка $\epsilon$ полігоном для випробовування нових форм та способів боротьби, створюють нові загрози для суспільства [7-10].

Аналіз останніх досліджень і публікацій. Інформаційне середовище сучасних країн являє собою інформаційно-комунікаційну частину разом з відповідними медіаресурсами та акторів, які визначають ціннісне наповнення та ідеологічну спрямованість інформаційного контенту.

У сучасному суспільстві визначились загальні тренди розвитку інформаційного простору як середовища для проведення інформаційних (психологічних) операцій (впливів) такі, як поступова трансформація класичних засобів масової інформації у засо- би масової комунікації (ЗМК), зникнення інтересу до газет та вихід на перший план соціальних мереж, поява нових технологій впливу на людську свідомість, об'єднання засобами масової комунікації функцій джерела інформації та каналу комунікації, а також самосегментація та орієнтація аудиторії споживачів інформації не на будь-які засоби масової комунікації, а лише на ті, що відповідають ії запитам $[11$, С. $72 ; 12 ; 13$, С. 139-140].

Разом 3 тим, сучасний інформаційний простір являє собою унікальну можливість отримання будьякої інформації за обраною проблемою за умови наявності відповідного інструментарію, застосування якого дозволяє аналізувати взаємозв'язок можливих подій або подій, які вже відбуваються, з інформаційною активністю визначеного кола джерел інформації.

В інформаційному просторі розрізняють основні та неосновні аудиторії [13, С. 143]. При цьому, основна цільова аудиторія може знаходитись у тісній взаємодії або у навколишньому оточенні інших потенційних цільових аудиторій. Тож, вихід із звичного стану та / або зміна поведінки (відношення) потенційних цільових аудиторій безпосередньо або опосередковано впливає на цільову аудиторію, що $є$ об'єктом впливу.

Ефективними вважають комунікації, що не вичерпуються спрямуванням на одну конкретну цільову аудиторію, а беруть до уваги ймовірні наслідки сприйняття конкретного інформаційного матеріалу (меседжу) всіма іншими можливими цільовими аудиторіями [14, С. 17]. 
Визначення цільової аудиторії (об'єкту впливу) передбачає аналіз іiі основних характеристик, виявлення пріоритетних каналів комунікації, встановлення найбільш сприятливого часу для здійснення IB. Для аналізу цільової аудиторії можуть використовуватись якісні і кількісні методи дослідження. В залежності від мети IB, що планується, визначаються конкретні методи - точкові, повторювані або вибіркові. Найбільш точні характеристики цільової аудиторії можна отримати за результатами аналізу активності в соціальних мережах. При цьому значна частина аналізу з достатньо високою точністю може здійснюватись автоматично. Використання технологій штучного інтелекту для створення психологічних портретів об'єктів IB за профілями у соціальних мережах суттєво підвищує точність визначення характеристик цільових аудиторій, а, відповідно, й ефективність впливу.

В ході підготовки та проведення інформаційної (психологічної) операції здійснюється вибір найбільш ефективного засобу масової комунікації на певну цільову аудиторію. Засоби впливу можуть застосовуватись різноманітні. Тож, оцінювання ефективності застосування засобів масової комунікації, що можуть бути використані в ході інформаційної (психологічної) операції, є актуальним науковим завданням.

Мета статті - розробка методичного підходу до вибору засобу масової комунікації для здійснення інформаційного (психологічного) впливу визначену цільову аудиторію (об’єкт впливу).

\section{Виклад основного матеріалу}

Ефективність застосування різних видів ЗМК пропонується оцінювати за двома складовими - комунікативною (ефективність інформаційного (психологічного) впливу на свідомість цільової аудиторії (об’єкту впливу)) та економічною (ефективність вкладених у процес здійснення інформаційного (психологічного) впливу коштів).

Для визначення ефективності застосування ЗМК пропонується низка характеристик (які можуть бути оцінені відповідними показниками) таких, як:

- кількість звернень до інформаційних матеріалів за певний проміжок часу;

- сприйняття цільовою аудиторією (об'єктом впливу) інформаційних матеріалів;

- періодичність виходу засобу масової комунікації;

- запам'ятовуваність змісту інформаційних матеріалів;

- вплив інформаційних матеріалів на поводження (зміну поведінки) цільової аудиторії (об'єкту впливу);

- загальна сума витрат, що забезпечують позитивний результат інформаційного (психологічного) впливу.
В залежності від цілей інформаційного (психологічного) впливу, характеристик цільової аудиторії та фінансового забезпечення перелік характеристик ЗМК і відповідних показників може змінюватись.

Ефективність впливу досягається переважно за допомогою формування необхідного емоційного відношення до певного інформаційного матеріалу. Через формування емоційного відношення до інформаційного матеріалу можна значно швидше отримати його позитивне або негативне сприйняття, ніж логічністю й аргументованістю викладення. Відповідним управлінням обсягом, послідовністю і спрямованістю фонетичних і лексичних значень інформаційних матеріалів можуть бути сформовані необхідні канали впливу. При цьому, слід враховувати оцінку емоційного впливу окремих слів (виразів, меседжів) інформаційного матеріалу та його фонетичної структури в цілому на свідомість людини, рівень агресивності та звуко-кольорові характеристики матеріалу, навантаження на сенсорні канали сприйняття людини тощо.

Оцінювання ефективності застосування засобу масової комунікації пропонується здійснювати шляхом проведення опитування за допомогою спеціально розроблених анкет. При цьому можуть використовуватись опитувальні панелі на офіційних сайтах визначених ЗМК або у соціальних мережах. Для отримання достовірних результатів при порівнянні ефективності декількох видів ЗМК тривалість розміщення анкет стосовно певних інформаційних матеріалів повинна бути однакова. При проведенні опитування необхідно враховувати пріоритетний час доби для певної цільової аудиторії (об'єкту впливу) - головний час (prime-time), денний час (day-time), час спорту (sports), час новин (news daypast), пізній нічний час (late night).

Опитування передбачене для всієї цільової аудиторії (об'єкту впливу). Якщо кількість осіб, що взяли участь в опитуванні, менше всієї цільової аудиторії, то при проведенні розрахунків чисельність цільової аудиторії зменшується до кількості осіб, що взяли участь в опитуванні.

В основу оцінювання ефективності застосування того або іншого засобу масової комунікації покладений критерій “результат / вартість”.

Узагальнений показник ефективності застосування ЗМК (Е) (від англ. efficiency) пропонується визначати за формулою:

$$
E=\frac{E_{k}}{E_{e}},
$$

де $E_{k}$ - комунікативна складова узагальненого показника ефективності застосування ЗМК;

$E_{e}$ - економічна складова узагальненого показника ефективності застосування ЗМК. 
Діапазон значень узагальненого показника ефективності застосування ЗМК знаходиться в інтервалі від 0 до 10 .

Комунікативну складову ефективності $\left(E_{k}\right)$ пропонується визначати за формулою:

$$
E_{k}=N_{\text {app }} \times K_{\text {perc }} \times n \times K_{m e m} \times I,
$$

де $N_{a p p}$ - кількість звернень (від англ. appeals) до інформаційних матеріалів за певний проміжок часу;

$$
K_{\text {perc }} \quad-\text { показник сприйняття (від }
$$

англ. perception) інформаційних матеріалів цільовою аудиторією (об'єктом впливу);

$n$ - коефіцієнт періодичності виходу ЗМК;

$K_{\text {mem }}$ - показник запам'ятовуваності (від англ. memorability) змісту інформаційних матеріалів;

I - ступінь впливу (від англ. impact) інформаційних матеріалів на поводження (зміну поведінки) цільової аудиторії (об'єкту впливу).

Показник кількості звернень до інформаційних матеріалів за певний проміжок часу характеризує частку цільової аудиторії, що ознайомилась з інформаційним матеріалом відносно загальної кількості цільової аудиторії даного випуску ЗМК (кількості реципієнтів, що взяли участь в опитуванні):

$$
N_{\text {app }}=\frac{N_{\text {fam }}}{N_{\text {poll }}},
$$

де $N_{f a m}$ - кількість людей, які повністю або частково ознайомилися з інформаційними матеріалами;

$N_{\text {poll }}$ - кількість осіб, що взяли участь в опитуванні (цільова аудиторія).

Показник сприйняття цільовою аудиторією (об'єктом впливу) інформаційних матеріалів характеризує відношення цільової аудиторії (об'єкту впливу) до інформаційних матеріалів певної спрямованості, у тому числі із використанням даного виду ЗМК:

$$
K_{\text {perc }}=\frac{N_{\text {pos }}}{N_{\text {poll }}},
$$

де $N_{p o s}$ - кількість осіб, що позитивно оцінюють інформаційні матеріали і вважають за необхідне продовжувати публікувати матеріали даної спрямованості у даному виді ЗМК. При проведенні розрахунків вважається, що $N_{p o s} \leq N_{f a m}$.

Коефіцієнт періодичності виходу ЗМК характеризує частоту оприлюднення інформаційних ма- теріалів конкретним ЗМК за певний період (місяць, тиждень) (табл. 1). У методичному підході пропонується встановити період 1 місяць.

Коефіціснт періодичності виходу ЗМК обумовлюється особливостями людської пам'яті. Так, короткочасна пам'ять практично повністю автоматична і працює без будь-якої свідомої установки на запам'ятовування. Людина може охопити поглядом близько семи предметів, запам'ятовуючи у середньому від п'яти до дев'яти одиниць інформації, які вона спроможна точно відтворити через кілька десятків секунд після їхнього пред'явлення. Тому, обгрунтовано вважають, що обсяг короткочасної пам'яті становить (7 \pm 2$)$ елементи [15].

Таблиця 1

Коефіцієнт періодичності виходу ЗМК

\begin{tabular}{|c|l|c|}
\hline $\begin{array}{c}\text { № } \\
\text { 3/п }\end{array}$ & $\begin{array}{l}\text { Кількість інформаційних } \\
\text { матеріалів протягом } \\
\text { місяця }\end{array}$ & $\begin{array}{c}\text { Коефіцієнт } \\
\text { періодичності } \\
\text { виходу 3МК }\end{array}$ \\
\hline 1. & $\begin{array}{l}\text { до 4-х (в середньому 1 } \\
\text { раз на тиждень) }\end{array}$ & 0,2 \\
\hline 2. & $\begin{array}{l}\text { від 5 до 8 (в середньому } \\
\text { до 2 разів на тиждень) }\end{array}$ & 0,5 \\
\hline 3. & $\begin{array}{l}\text { від 9 до 12 (в середньому } \\
\text { до 3 разів на тиждень) }\end{array}$ & 0,7 \\
\hline 4. & $\begin{array}{l}\text { від 13 до 31 (більше ніж } \\
\text { 3 рази на тиждень) }\end{array}$ & 1 \\
\hline
\end{tabular}

Джерело: розроблено авторами.

Довготривала пам'ять забезпечує людині тривале збереження інформації. Встановлено що інформація найкраще запам'ятовується, якщо до неї повертатися через визначені проміжки часу. Перший становить 15-20 хвилин, що пов'язано із роботою короткочасної пам'яті. Через дві години в людини включаються функції довгострокової пам'яті. Найкраще повернутися до матеріалу через вісім годин та через добу.

Події, що запам'ятовуються в короткочасній пам'яті, швидко забуваються, у той час як події, що залишилися в довготривалій пам'яті, запам'ятовуються надовго і можуть бути відновлені через багато років.

Показник запам'ятовуваності змісту інформаційних матеріалів характеризує частку цільової аудиторії, яка запам'ятала зміст матеріалів і спроможна частково або повністю його відтворити через незначний проміжок часу, відносно загальної кількості цільової аудиторії з урахуванням того, що опитування проведене серед всієї цільової аудиторії:

$$
K_{\text {mem }}=\frac{N_{\text {mem }}}{N_{\text {poll }}},
$$

де $N_{\text {mет }}$ - кількість осіб, яка запам'ятала зміст матеріалів і спроможна повністю його відтворити че- 
рез незначний проміжок часу. При проведенні розрахунків вважається, що $N_{\text {mem }} \leq N_{\text {fam }}$.

Ступінь впливу інформаційних матеріалів на поводження (зміну поведінки) цільової аудиторії (об'єкту впливу) пропонується визначати за формулою:

$$
I=\frac{N_{i}}{N_{\text {poll }}},
$$

де $N_{i}$ - кількість осіб, яка змінила свою поведінку (думку щодо певних подій, фактів, обставин тощо) або планує це зробити під впливом інформаційних матеріалів.

Таблиця 2

Чисельна оцінка економічної складової узагальненого показника ефективності застосування ЗМК

\begin{tabular}{|c|c|c|}
\hline $\begin{array}{c}\text { № } \\
3 / п\end{array}$ & $\begin{array}{c}\text { Загальна сума витрат на розробку } \\
\text { і розміщення інформаційного } \\
\text { контенту, тис. грн. }\end{array}$ & $E_{e}$ \\
\hline 1. & до 100 & 0,1 \\
\hline 2. & від 100 до 300 & 0,3 \\
\hline 3. & від 300 до 500 & 0,5 \\
\hline 4. & від 500 до 1000 & 0,8 \\
\hline 5. & понад 1000 & 1 \\
\hline
\end{tabular}

Джерело: розроблено авторами.

Економічна складова узагальненого показника ефективності застосування ЗМК $\left(E_{e}\right)$ визначається, виходячи із загальної суми витрат на розробку i розміщення інформаційного контенту в ЗМК. Суми витрат визначені орієнтовно і можуть корегуватись залежно від вартості інформаційного контенту і виду ЗМК, де передбачається його розміщення, економічної обстановки в країні, курсу національної ва- люти, рівня інфляції тощо. Чисельна оцінка економічної складової узагальненого показника ефективності застосування ЗМК представлена у табл. 2.

Отримане чисельне значення узагальненого показника ефективності застосування ЗМК дозволяє здійснювати вибір засобу масової комунікації з урахуванням цілей інформаційного (психологічного) впливу, характеристик конкретного засобу та цільової аудиторії (об’єкту впливу).

\section{Висновки}

Загальні тренди розвитку інформаційного простору як середовища для проведення інформаційних та психологічних операцій (впливів) свідчать про зростання рівня загроз в інформаційному просторі.

Методичний підхід до вибору засобу масової комунікації для здійснення інформаційного (психологічного) впливу на визначену цільову аудиторію (об'єкт впливу) має системний характер, передбачає апостеріорну оцінку результатів та дозволяє порівнювати доцільність застосування засобів масової комунікації за критерієм результат / вартість.

Даний методичний підхід дозволяє обирати найбільш доцільний засіб масової комунікації серед засобів одного типу (друковане видання, електронне видання, телевізійна програма тощо), але може бути доопрацьований для порівняння ЗМК різних типів.

В основу даного методичного підходу покладений один із індивідуальних експертних методів, а саме анкетування, що передбачає використання думок експертів, у якості яких, у даному випадку, виступають всі члени цільової аудиторії, які сформульовані особисто кожним із них самостійно незалежно від інших, а потім ці оцінки об'єднуються у загальну оцінку.

\section{Список літератури}

1. Деркаченко Я. Інформаційно-психологічні операції як сучасний інструмент геополітики. Глобальна організачія союзницького лідерства. 2016. URL : http://goal-int.org/informacijno-psixologichni-operacii-yak-suchasnij-instrumentgeopolitiki/ (дата звернення: 13.04.2021).

2. Шевчук П. І. Інформаційно-психологічна війна Росії проти України: як їй протидіяти. Демократичне врядування. 2014. Вип. 13. URL : http://nbuv.gov.ua/UJRN/DeVr_2014_13_11 (дата звернення: 14.04.2021).

3. Мороз Ю., Твердохліб Ю. Інформаційно-психологічні операції в умовах гібридної війни. Вісник Львівського університету. Серія міжнародні відносини. 2016. Issue 38. C. 97-105. http://nbuv.gov.ua/UJRN/VLNU_Mv_2016_38_12.

4. Хворост Х. Ю. Інформаційно-психологічний вплив у розрізі безпеки здоров’я. Наука $і$ освіта. 2016. № 2-3. C. 184-191. https://doi.org/10.24195/2414-4665-2016-2-3-33.

5. Курбан О. В. Сучасні інформаційні війни в мережевому он-лайн просторі. Київ : ВІКНУ, 2016. 286 с.

6. Військовий стандарт ВСТ 01.004.007-2017(1). Воєнна політика, безпека та стратегічне планування. Система стратегічних комунікацій держави у воєнній сфері. Терміни та визначення. [Чинний від 2017-12-20]. Вид. офіц. Київ, 2017. 47 с. (Інформація та документація).

7. Інформаційно-психологічна боротьба у воєнній сфері : монографія / Пєвцов Г. В. та ін. Харків : вид. Рожко С. Г., 2017. 276 c.

8. Улічев О. С., Мелешко С. В. Програмне моделювання поширення інформаційно-психологічних впливів у віртуальних соціальних мережах. Сучасні інформаційні системи. 2018. Т. 2. № 2. С. 35-39. https://doi.org/10.20998/25229052.2018.2.06.

9. Сасин Г. В. Кольорові революції: сутність, основні риси, причини виникнення та політичні наслідки. Science and Education a New Dimension. Humanities and Social Sciences. 2015. III(7). Issue : 42. C. 40-42. 
10. Пашенцев Е. Н. Злонамеренное использование искусственного интеллекта: новые угрозы для международной информационно-психологической безопасности и пути их нейтрализации. Государственное управление. Электронный вестник.Вып. № 76. 2019. С. 279-300. URL : https://cyberleninka.ru/article/n/zlonamerennoe-ispolzovanie-iskusstvennogointellekta-novye-ugrozy-dlya-mezhdunarodnoy-informatsionno-psihologicheskoy-bezopasnosti/viewer (дата звернення: 14.05.2021).

11. Хударковський К. І., Залкін С. В., Пєвцов Г. В., Пацек П., Сідченко С.О. Механізм протидії негативному інформаційно-психологічному впливу на особовий склад Збройних Сил України. Наука і техніка Повітряних Сил. 2020. № 1(38). C. 72-78. https://doi.org/10.30748/nitps.2020.38.08.

12. Гусаров В. Силы информационных операций России: каким должен быть ответ Украины? ArmyUA: Аналітично-інформаційний портал. URL : https:/www.armyua.com.ua/sily-informacionnyx-operacij-rossii-kakim-dolzhen-byt-otvetukrainy/ (дата звернення: 14.05.2021).

13. Інформаційно-психологічні операції: планування, протидія, технології : монографія / Пєвцов Г. В., Залкін С. В., Сідченко С. О., Хударковський К. І. Харків. : ДІСА ПЛЮС. 2020. 252 с.

14. Panasiuk A., Zubrytska H. Information Support of Russian Media for the Tourist Destination of Crimea. Sustainability. 2021. 13(6):3228. https://doi.org/10.3390/su13063228.

15. Лимонова О. О., Диговцов Г. В. Особенности проявления памяти и её влияние на жизнь человека. Приоритетные научные направления: от теории к практике. 2017. - С. 88-91.

\section{Відомості про авторів:}

Псвцов Геннадій Володимирович доктор технічних наук професор заступник начальника Харківського національного університету Повітряних Сил ім. І. Кожедуба 3 наукової роботи,

Харків, Україна

https://orcid.org/0000-0002-0426-6768

Пацек Петро

доктор філософії

викладач

Академії військового мистецтва,

Варшава, Польща

https://orcid.org/0000-0002-2182-2316

Кас'яненко Максим Вікторович

кандидат військових наук

Департаменту військової освіти і науки

Міністерства оборони України,

Київ, Україна,

https://orcid.org/0000-0002-3749-4441

Залкін Сергій Володимирович

кандидат військових наук старший науковий співробітник провідний науковий співробітник

Харківського національного університету

Повітряних Сил ім. І. Кожедуба,

Харків, Україна

https://orcid.org/0000-0002-0518-4414

\section{Сідченко Сергій Олександрович}

кандидат технічних наук старший науковий співробітник докторант Харківського національного університету Повітряних Сил ім. І. Кожедуба, Харків, Україна

https://orcid.org/0000-0002-1319-6263

Хударковський Костянтин Ігорович

кандидат технічних наук доцент

старший науковий співробітник старший науковий співробітник

Харківського національного університету

Повітряних Сил ім. І. Кожедуба,

Харків, Україна

https://orcid.org/0000-0002-9508-9014

\section{Information about the authors:}

\section{Hennadii Pievtsov}

Doctor of Technical Sciences Professor

Deputy Head of Ivan Kozhedub

Kharkiv National Air Force University

in Science,

Kharkiv, Ukraine

https://orcid.org/0000-0002-0426-6768

\section{Piotr Pacek}

Doctor of Philosophy

Lecturer

of The War Studies University,

Warsaw, Poland

https://orcid.org/0000-0002-2182-2316

\section{Maksym Kasianenko}

Candidate of Military Sciences

of Department of Military Education and Science

of Ministry of Defence of Ukraine,

Kyiv, Ukraine

https://orcid.org/0000-0002-3749-4441

\section{Sergii Zalkin}

Candidate of Military Sciences Senior Research

Lead Research

of Ivan Kozhedub

Kharkiv National Air Force University,

Kharkiv, Ukraine

https://orcid.org/0000-0002-0518-4414

\section{Sergii Sidchenko}

Candidate of Technical Sciences Senior Research

Doctoral Student

of Ivan Kozhedub Kharkiv National Air Force University,

Kharkiv, Ukraine

https://orcid.org/0000-0002-1319-6263

\section{Konstantin Khudarkovskij}

Candidate of Technical Sciences Associate Professor

Senior Research

Senior Research Associate

of Ivan Kozhedub Kharkiv National

Air Force University,

Kharkiv, Ukraine

https://orcid.org/0000-0002-9508-9014 


\section{МЕТОДИЧЕСКИЙ ПОДХОД К ВЫБОРУ СРЕДСТВА МАССОВОЙ КОММУНИКАЦИИ ДЛЯ ОСУЩЕСТВЛЕНИЯ ИНФОРМАЦИОННОГО (ПСИХОЛОГИЧЕСКОГО) ВОЗДЕЙСТВИЯ}

Г.В. Певцов, П. Пацек, М.В. Касьяненко, С.В. Залкин, С.А. Сидченко, К.И. Хударковский

В статье определены общие тренды развития информационного пространства как среды для проведения информачионных и психологических операций (воздействий), представлен методический подход к выбору средства массовой коммуникаиии в ходе подготовки и проведения информачионной (психологической) операции (воздействия), в основу которого положен критерий "результат / стоимость". Для выбора средства массовой коммуникации предложен ряд характеристик, которые могут быть оченены соответствуюшими показателями путем проведения опроса с помощью специально разработанных анкет. Определение обобщенного показателя эффективности применения средства массовой коммуникации позволяет выбирать средство массовой коммуникации, которое наиболее соответствует иелям информационного (психологического) воздействия. Экономическая составляющая обобщенного показателя эффективности применения средства массовой коммуникации определяется, исходя из общей суммы затрат на разработку и размещение информационного контента.

Ключевые слова: информационное (психологическое) воздействие, информационная (психологическая) операчия, объект информационного воздействия, целевая аудитория.

\section{METHODICAL APPROACH TO THE CHOICE OF MASS COMMUNICATION MEANS FOR IMPLEMENTING INFORMATION (PSYCHOLOGICAL) INFLUENCE}

H. Pievtsov, P. Pacek, M. Kasianenko, S. Zalkin, S. Sidchenko, K. Khudarkovskij

The article identifies general trends in the development of information space as an environment for information and psychological operations (influences), target audiences and methods of their analysis. It is noted that there is a gradual transformation of the media, growing interest in social networks, the emergence of new technologies to influence human consciousness, the media combine the functions of the source of information and communication channel. It is noted that communications that are not limited to one specific target audience are considered effective, but take into account the probable consequences of the perception of a particular message by all other possible target audiences. The use of artificial intelligence technologies to create psychological portraits of objects of informational influence on the profile in social networks significantly increases the accuracy of determining the characteristics of target audiences.

The purpose of the article is to develop a methodical approach to the choice of media during the preparation and conduct of information (psychological) operation (impact), which is based on the criterion of "result / cost". To choose the media, a number of characteristics are proposed, which can be assessed by relevant indicators by conducting a survey using specially designed questionnaires. Determining the generalized indicator of the effectiveness of the use of the media allows you to choose the media that best meets the goals of information (psychological) influences. The economic component of the effectiveness of the use of the media is determined based on the total cost of development and placement of information content. The amount of costs is estimated and can be adjusted depending on the cost of information content and the type of media.

The methodical approach to the choice of mass media for information (psychological) influence on a specific target audience is systematic, provides a posteriori evaluation of results and allows to compare the feasibility of using the media.

Keywords: informational (psychological) influence, informational (psychological) operation, object of informational influence, target audience. 